\title{
TRANSMISSION ELECTRON MICROSCOPY STUDY OF VERY LOW-GRADE METAMORPHIC ROCKS IN CAMBRIAN SANDSTONES AND SHALES, OSSA-MORENA ZONE, SOUTHWEST SPAIN
}

\author{
A. López-Munguira ${ }^{1}$ AND F. Nieto ${ }^{2}$ \\ ${ }^{1}$ Area de Cristalografía y Mineralogía, Facultad de Ciencias, Universidad de Extremadura, \\ Avda. de Elvas s/n, 06071-Badajoz, Spain \\ 2 Departamento de Mineralogía y Petrología and I.A.C.T., Universidad de Granada-CSIC, \\ Avda. Fuentenueva s/n, 18002-Granada, Spain
}

\begin{abstract}
This study examines the evolution of the texture, structure, and chemical composition of rocks derived from clastic materials of the Ossa-Morena Zone (Hesperian Massif, Spain). Previous studies of phyllosilicates in these rocks (by X-ray diffraction, scanning electron microscopy with energy-dispersive $\mathrm{X}$-ray analysis, and electron microprobe) indicated a temperature decrease from bottom (epizone conditions) to top (diagenetic conditions) of the rock section.

At the nanometer scale, phyllosilicate packets form large angles where grains intersect with no preferred orientation. With metamorphic grade, packets are wide and defect free, compared to packets at lower grade. These packets are $\sim 15$ layers under diagenetic conditions to $>80$ layers in the epizone. Dioctahedral K-rich micas (muscovite, phengite, and illite) have coexisting $1 M_{d}, 1 M$, and $2 M$ polytypes. Longperiod polytypes of 4,5 , and 6 layers are reported for the first time in dioctahedral K-rich micas. The chemical compositions of the micas are nearly identical in the anchizone and the diagenetic zone, comprising an illitic ( 0.8 atoms per formula unit, a.f.u., of $\mathrm{K}$ ) and a phengitic component ( 0.15 a.f.u. of $\mathrm{Mg}$ and 0.13 a.f.u. of $\mathrm{Fe}$ ). Fe may correspond to a ferrimuscovitic substitution. Epizone samples have a high phengitic content ( $\mathrm{Mg}=0.24$ a.f.u.) and almost no illite component. One diagenetic sample has coexisting berthierine, trioctahedral chlorite, sudoite, and corrensite. Berthierine and chlorite are identical in composition. Because of the clastic nature of the system, the composition of corrensite is not typical of other corrensites, with higher $\mathrm{Al}$ content, $\mathrm{Fe} / \mathrm{Mg}$ ratio at $\sim 1$, and $\mathrm{K}$ as the exchangeable cation.

Textural differences between the diagenetic zone and the anchizone are the progressive increase in the size of dioctahedral K-rich mica grains, which involves an increasing illite crystallinity based on the Kübler index. The chemical compositions of these micas are illite (diagenesis and anchizone) and phengite in the epizone. There are no intermediate phases, suggesting a compositional gap between illite and phengite. The coexistence of different polytypes of dioctahedral K-rich micas and the absence of chemical homogeneity indicate disequilibrium in the Cambrian pelitic rocks studied
\end{abstract}

Key Words-AEM, Anchizone, Chloritic Phases, Clastic Rocks, Mica, Polytypes, Variscan Belt.

\section{INTRODUCTION}

The detailed knowledge of the texture and chemistry of mineral phases in pelitic sediments affected by diagenesis and/or very low-grade metamorphism remains incomplete owing to the structural defects in these phases. Moreover, fine-grain size requires sophisticated techniques for study, such as high-resolution electron microscopy (HRTEM) and analytical electron microscopy (AEM). In recent years, HRTEM studies have been performed on numerous "type" rock sequences (with well-known conditions of formation) to clarify the chemical and microstructural changes that occur during diagenesis and incipient metamorphism. Examples of such studies include sequences in the Gulf Coast (e.g., Ahn and Peacor, 1986), Salton Sea (Yau et al., 1987), North Sea (Lindgreen and Hansen, 1991), Basque-Cantabrian Basin (Nieto et al., 1996), Diablo Range (Dalla-Torre et al., 1996), and Cornwall (Warr and Nieto, 1998). These studies focused on the significance of the original sediment lithology, the subsequent tectonic history, and other factors.
The lithology of these sequences is fine grained. There is therefore a lack of understanding of the effect of sandier lithologies, where the mineralogical changes occurring during diagenesis to low-grade metamorphism may be different from fine-grained sequences. For instance, in sequences with larger grain-size lithologies there is incomplete dissolution of grains and precipitation of new phases (Lee et al., 1985). Also, greater permeability allows a higher fluid/sediment ratio, with a consequent dominance of dissolution/neoformation processes (Yau et al., 1987).

López-Munguira et al. (1998) described a volcanosedimentary continuous Cambrian silty-sandy sequence in the Hesperian Massif of Southwest Spain. The evolution of the sequence shows an increase in metamorphic grade from top to bottom (established by $I C$, illite crystallinity), ranging from diagenesis to epizone. Moreover, in chlorite from basic rocks associated with the sequence, they found a decrease in smectite layers toward the bottom (concomitant with an apparent temperature increase). These authors determined that the coexistence of $1 M$ and $2 M$ polytypes 


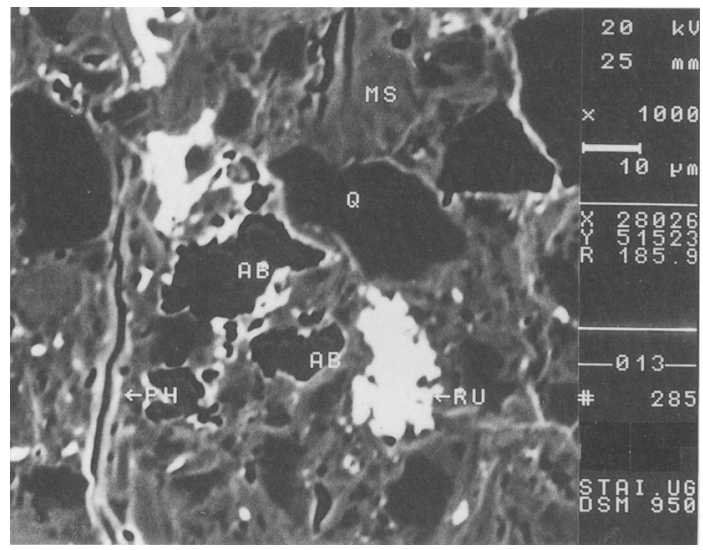

Figure 1. Representative backscattered image of the texture of the Zafra clastic rocks. No significant differences in texture can be recognized at SEM scale from bottom to top of the sequence. Diagenetic sample (C90-7). $A B=$ albite; $Q=$ quartz; FK = potassium-rich feldspar; $\mathrm{MS}=$ muscovite; $\mathrm{PH}$ $=$ phengite; $\mathrm{RU}=$ rutile

of the dioctahedral micas in the less-metamorphosed samples demonstrated disequilibrium at the top of the series. Thus, the genetic relationship between the polytypes of this sequence is complex.

This study involves a detailed analysis of the texture, structure, polytype, and chemical composition of phyllosilicates using HRTEM/AEM to determine the effect of metamorphism as applied to sandy sequences. Representative clastic samples (López-Munguira et al., 1998) were obtained from the Cambrian series based on data from X-ray diffraction (XRD) and scanning electron microscopy (SEM). The composition and microstructures of the phyllosilicates at different metamorphic grades were compared.

\section{MATERIALS AND METHODS}

The Cambrian rocks from Northwest Zafra, OssaMorena Zone, southwest Spain (Julivert et al., 1974) are composed of clastic and volcanic materials. Detritic lithologies consist of terrigenous sediments (arkoses) at the base of the series and sandstones and shales, deposited in a shallow-marine platform environment, near the top. The main deformational phases are Hercynian in time and these deformational phases produced very low-grade regional metamorphism. The mineral assemblage is quartz, albite, dioctahedral mica, chlorite, and berthierine, with rutile, zircon, pyrite, apatite, and hematite as accessory minerals. Textures consist of elongated mica crystals surrounding quartz and albite crystals. The matrix, comprising mica and other phyllosilicates, is submicron in size and unresolved at the SEM scale (Figure 1).

The metamorphic evolution of these rocks was studied by López-Munguira et al. (1993, 1996, 1998). They obtained the crystal-chemical parameters $[d(001), b$ cell parameter, $d(00 l)$-intensity ratios, and illite-cystallinity index, $I C]$ of phyllosilicates by XRD. SEM and energy dispersive X-ray (EDX) analyses of selected areas were also made, as well as electron microprobe studies of metamorphic minerals in the volcanic rocks. Nevertheless, the composition and textures of the matrix-forming phyllosilicates below the resolution of the SEM remains poorly known. The phengite and muscovite $I C$ data are of three types: (1) micas from the Basal Cambrian have an average $I C$ value of $0.25(4) \Delta^{\circ} 2 \theta$, (2) in the remaining Lower Cambrian, the average $I C$ value is $0.38(5) \Delta^{\circ} 2 \theta$, and (3) Middle-Upper Cambrian micas have an average IC value of $0.50(7) \Delta^{\circ} 2 \theta$.

Clastic samples representing this sequence were chosen for HRTEM study based on XRD and SEM data: one sample from the basal Cambrian corresponding to epizone (ZL-11); one from the Lower Cambrian corresponding to anchizone (LP-6); and two from the Middle-Upper Cambrian corresponding to diagenetic conditions (C90-7 for the Middle Cambrian and C9125 for the Upper Cambrian). Samples C91-25 and C90-7 were selected owing to their different compositions and mineralogies.

\section{TEM}

Samples were prepared as thin sections mounted with Canada Balsam oriented approximately normal to bedding. Thin sections were examined using optical microscopy and SEM. Samples were ion thinned using a Gatan 600 ion mill and carbon coated. A Philips CM-20 scanning transmission electron microscope (STEM) equipped with an ultrathin window EDX detector (Centro de Instrumentación Científica, C.I.C., Granada University) was used. Quantitative analyses were obtained only from thin edges, using a $70-\AA$ beam diameter and a $1000 \times 200-\AA$ scanning area, with the long axis oriented parallel to the phyllosilicate packets. The sample was tilted $20^{\circ}$ toward the detector, to give an X-ray take-off angle of $34^{\circ}$. Albite, biotite, spessartine, muscovite, olivine, titanite, $\mathrm{SO}_{4} \mathrm{Ca}$, and $\mathrm{SO}_{4} \mathrm{Mn}$ standards were used to obtain K-factors for the transformation of intensity ratios to concentration following Cliff and Lorimer (1975) and Champness et al. (1981). Oxygen was not measured quantitatively. Formulae were determined from atomic concentration ratios based on the number of oxygen atoms in the ideal formula. ${ }^{\mathrm{IV}} \mathrm{Al}$ was calculated by difference from $\mathrm{Si}$ and ${ }^{\mathrm{v}} \mathrm{Al}=\mathrm{Al}_{\text {total }}-{ }^{\mathrm{N}} \mathrm{Al}$.

Alkali loss, especially $\mathrm{K}$, is a significant problem in the analysis of clay minerals (Van der Pluijm et al., 1988). Comparison of analyses obtained for counting times of 15-100 s showed that shorter counting times gave improved reproducibility for these elements; therefore, counting times of $15 \mathrm{~s}$ were used for alkali analysis (Nieto et al., 1996). Moreover, powders were prepared using holey $\mathrm{C}$-coated $\mathrm{Cu}$ grids for AEM of phyllosilicates to minimize alkali-loss problems. Indi- 


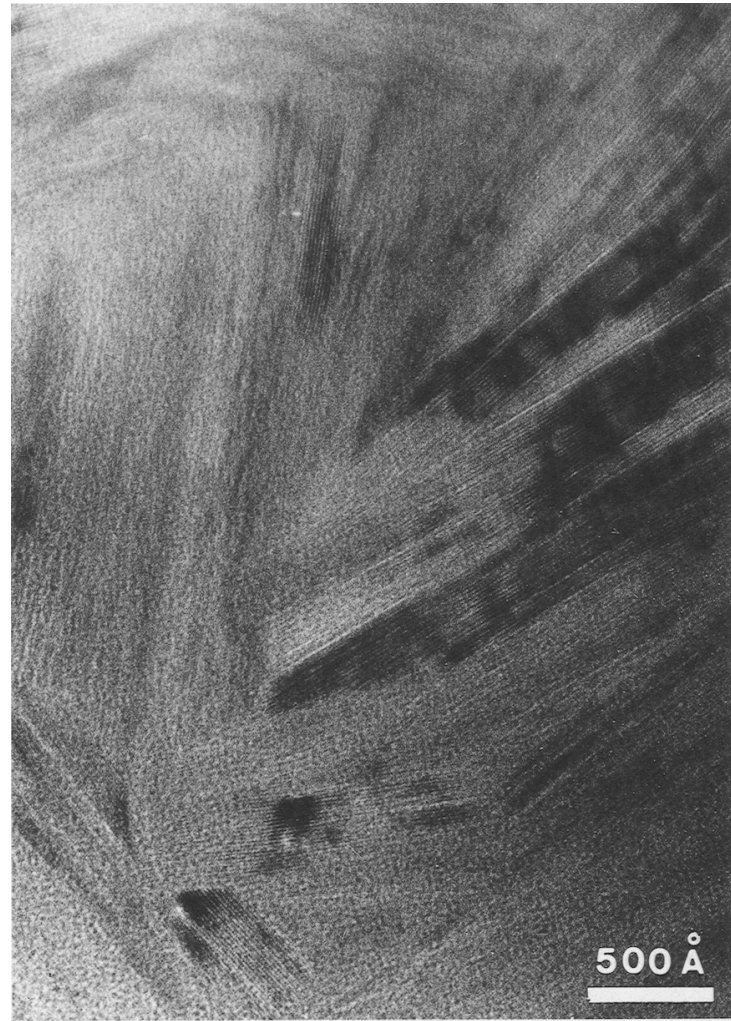

Figure 2. Lattice-fringe image showing a typical texture of the Zafra clastic rocks. Anchizone sample (LP-6).

vidual crystals, examined by single-crystal electron diffraction, were analyzed using a $1 \times 1 \mu \mathrm{m}$ scanning area. Both sets of data were used jointly as the powdered samples offer better analytical quality, but the ion-milled samples can relate texture information of the grain analyzed.

\section{RESULTS}

At low magnification, TEM showed no differences in texture among distinct samples. Generally, grains have no preferred orientation and the phyllosilicate packets are crossed, forming large intergrain angles (Figure 2). Below we describe the results obtained by HRTEM for each sample.

\section{$Z L-11$}

This sample is representative of the Basal Cambrian. The parameters established by López-Munguira $e t$ al. (1998) for this section are $I C=0.25(4) \Delta^{\circ} 2 \theta$ and $b=9.033(6) \AA$, indicating epizone conditions and an intermediate pressure regime. The phyllosilicates are almost exclusively phengite. The crystals consist of packets some 80-150 layers thick, which cross to form wide angles. Crystalline defects of note are curved layers and abundant low-angle edges. The dominant polytype is $2 M$, although polytype $1 M$ also occurs in appreciable amounts. In the same areas, 20 - $\AA$ periodicity is recognized within a packet showing a $10-\AA$ general periodicity. The thickness of such packets is variable between 10-40 layers. López-Munguira et al. (1998) found no evidence of the $1 M$ polytype in the epizone sample by XRD.

Relatively large ( $>0.5 \mu \mathrm{m}$ wide), defect-free crystals have apparent long-period sequences, with 4,5 , and 6 layers (Figure 3). The coexistence of these sequences is recognized, and they show lattice continuity. The four-layer sequence shows $k \neq 3 n$ reflections with a periodicity of $40 \AA$, and the $k=3 n$ reflections have a periodicity of $10 \AA$. This is similar for the 50 $\AA$ (5 layers) and $60-\AA$ (6 layers) sequences, which may be related to the combination of simple polytypes such as $(3+1,2+2)=40 \AA,(2+3,2+2+1)=50$ $\AA$, or $(2+2+2,3+3)=60 \AA$. Lattice-fringe images suggest that the layer combination is $(3+1)=4,(2$ $+3)=5$, and $(2+2+2)=6$, respectively. Nevertheless, actual stacking sequences cannot be defined by using one orientation of the crystal. Identification of true sequences rather than apparent sequences requires a minimum of two reciprocal nets containing $b^{*}$ or the pseudo- $b^{*}$ axis (Iijima and Buseck, 1978). Ross et al. (1966), Baronnet and Kang (1989), and Baronnet (1992) have shown that monoclinic symmetry is more common than triclinic symmetry, although more study is required to show this here. To our knowledge, this is the first reported occurrence of these polytypes in natural muscovites-phengites, although they were reported in other dioctahedral (Ahn et al., 1985) and trioctahedral micas, particularly biotites (Ross et al., 1966; Baronnet and Kang; 1989; Baronnet, 1992).

\section{$L P-6$}

This sample is representative of the Lower Cambrian. The phengite crystal-chemical data obtained by López-Munguira et al. (1998), IC $=0.38(5) \Delta^{\circ} 2 \theta$ and $b=9.011(5) \AA$, place this section in the anchizone, within an intermediate pressure regime. The illite crystals tend to form without preferred orientation. There are crossed packets with a variable number of layers (40-100), curved layers, and frequent displaced edges (Figure 2). Apparent $2 M$ and $1 M_{d}$ polytypes were identified. The $1 M_{d}$ packets show $10-\AA$ spacing along $k \neq$ $3 n$ rows within a near complete line of streaking.

The biotites, distinguished from muscovite by AEM, are disordered, and sometimes have low-angle boundaries. A mean formula, based on ten analyses is: $\left(\mathrm{Si}_{2.82} \mathrm{Al}_{1.19}\right) \mathrm{O}_{10}(\mathrm{OH})_{2}\left(\mathrm{Al}_{0.78} \mathrm{Mg}_{0.69} \mathrm{Fe}_{1.56} \mathrm{Ti}_{0.02}\right)_{\mathrm{\Sigma}=3.05}\left(\mathrm{~K}_{0.33^{-}}\right.$ $\left.\mathrm{Na}_{0.09}\right)$ and are thus $\mathrm{Al}-$ and $\mathrm{Mg}$-rich annites. Layers $(10-\AA)$ were observed to coherently pass laterally to $14-\AA \AA$ chlorite (Figure $4 a$ ), with some grains showing stacking layers alternating between layers of apparent $10-\AA$ and $14-\AA$ spacing (Figure 4b). This explains why most "biotite" crystals have an apparent intermediate 

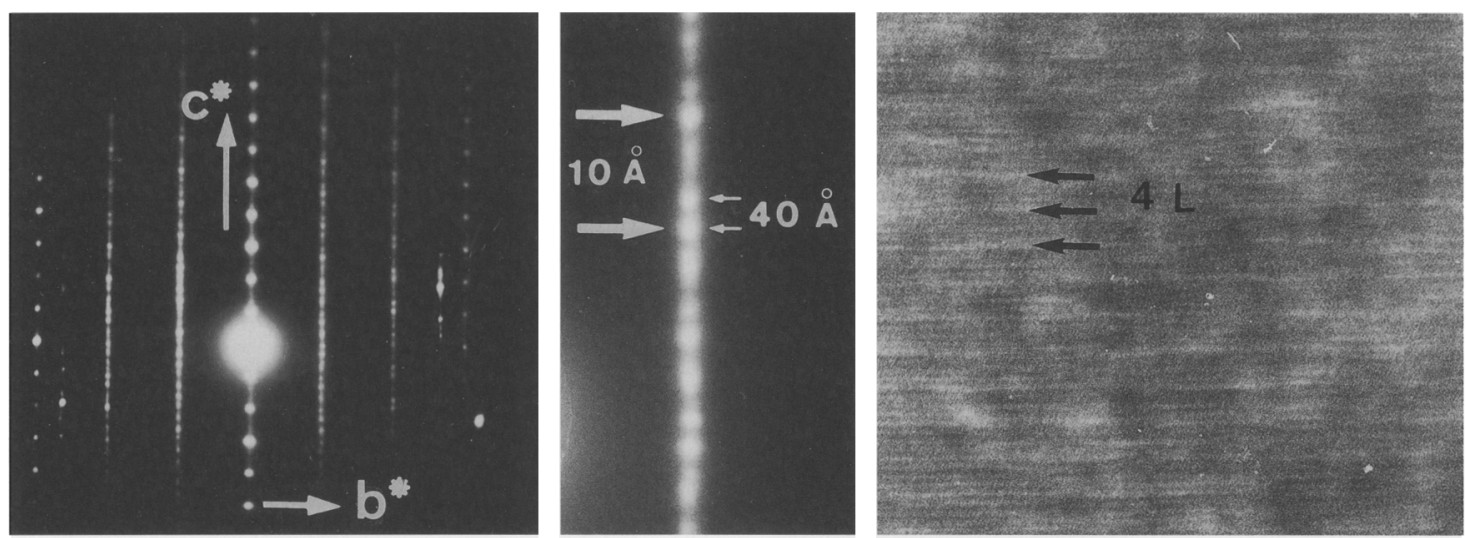

$k=2$
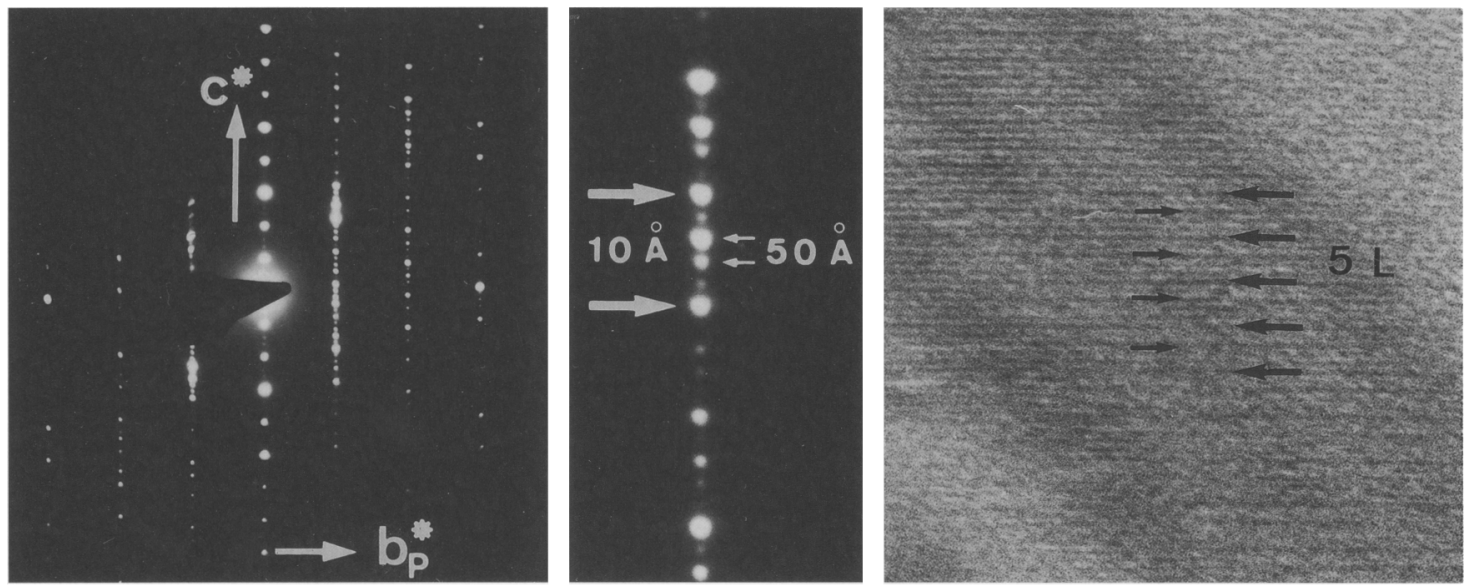

$\mathrm{k}=4$
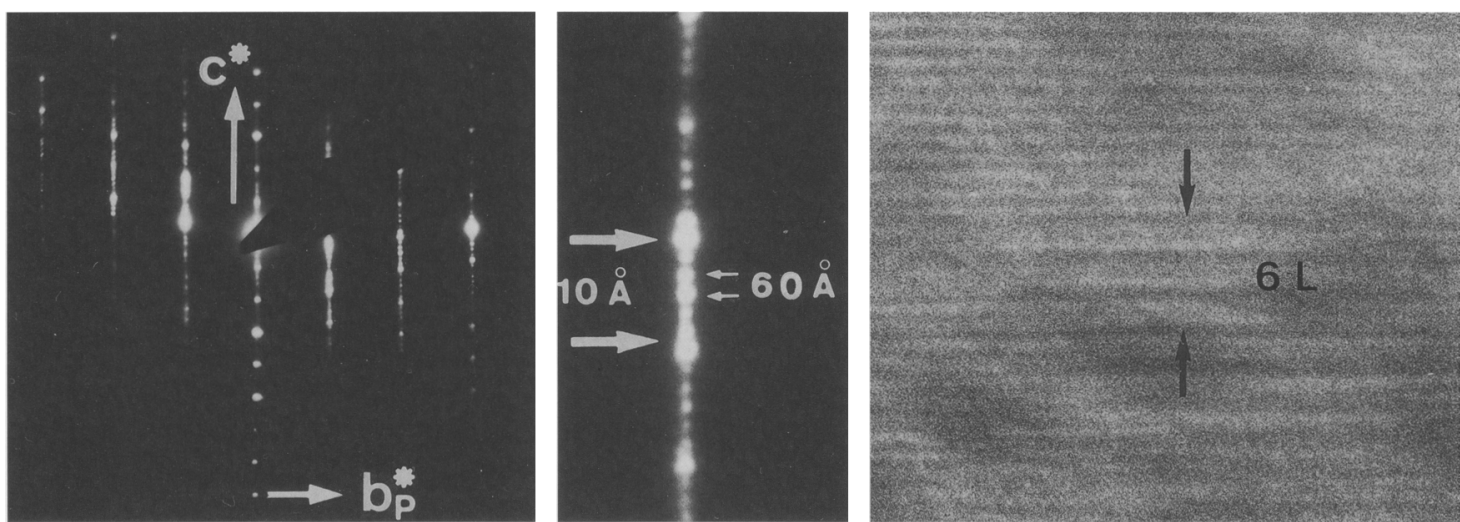

$$
\mathrm{k}=4
$$

Figure 3. SAED patterns and lattice-fringe images showing four-, five-, and six-layer sequences in dioctahedral K-rich micas from the epizone sample. Superperiodicity is noted both in the SAED patterns $(k \neq 3 n$ rows) and lattice-fringe images. Left: pattern view along [100] or equivalent $\langle 130\rangle$; center: $k$-row; right: lattice-fringe image. $b_{\mathrm{p}}^{*}$; pseudo- $b^{*}$ axis. 

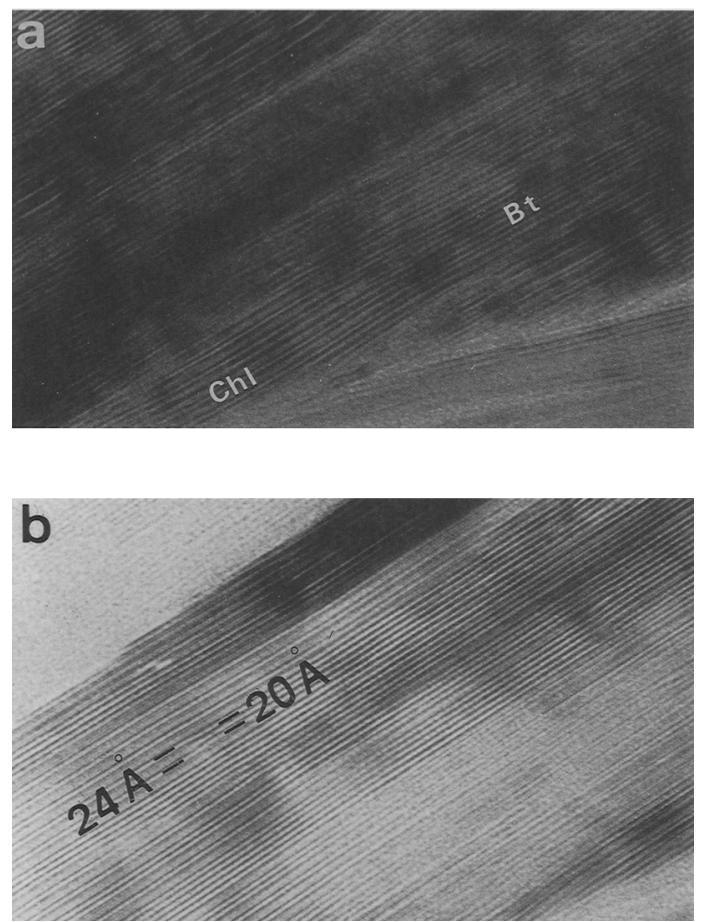

Figure 4 . a) Solid-state transformation from biotite to chlorite; b) replacement of the biotite interlayer cation by a brucite-like octahedral sheet (see Baronnet, 1992). Anchizone sample. $\mathrm{Chl}=$ chlorite; $\mathrm{Bt}=$ biotite.

composition between biotite and chlorite (López-Munguira et al., (1998). Rutile (1.5- $\mu \mathrm{m}$ crystals) and $\mathrm{Fe}$ oxides are very abundant throughout the sample also.

\section{C90-7}

This sample is representative of the Middle Cambrian. The crystal-chemical parameters determined by López-Munguira et al. (1998), IC $=0.50$ (7) $\Delta^{\circ} 2 \theta$ and $b=8.997(5) \AA$, indicate diagenesis and an apparent low-pressure regime, although this apparent regime is based on non-reequilibrated detritic micas, which are very abundant in the sample. This conclusion, reached by López-Munguira et al. (1998) from XRD and SEM data, is confirmed by the AEM data in the present work (see below). There are no significant differences in the degree of mica phengitization in the matrix between the samples. Illite is the only phyllosilicate present and it exists as apparent polytypes $1 M, 2 M$, and $1 M_{d^{*}}$

This sample is texturally similar to the anchizone sample. The crystals show anastomosed, curved, and open layers and low-angle edges separating (defectfree) packets ranging in size from $\sim 20$ to 50 layers.

\section{C91-25}

This sample corresponds to Upper Cambrian. The mica crystal-chemical parameters for this sample, determined by López-Munguira et al. (1998), $I C=0.56$
${ }^{\circ} \Delta 2 \theta$ and $b=8.992 \AA$, indicate that it is diagenetic, like sample C90-7. This sample was chosen owing to its varied mineralogy. XRD and SEM showed dioctahedral mica and berthierine as major phyllosilicate phases and trioctahedral chlorite as a minor phase. In addition, HRTEM showed sudoite (di-trioctahedral chlorite) and corrensite.

The textures obtained by HRTEM are typical of diagenetic samples and similar to sample C90-7. There are small (15-20 layers), unoriented packets of phyllosilicates with variable contrast. The phyllosilicates generally have a preferred orientation. Chlorite and berthierine are intergrown such that $7-\AA$ packets are adjacent to 14- $\AA$ packets, with identical chemical compositions (see below). In other cases, the chlorite and/ or berthierine are related to the mica, with a packet of one phase alternating with that of another. The berthierine is frequently associated with $\mathrm{Fe}$ oxides. In general, the most common defects are edge dislocations.

Apparently, illite forms as $1 M, 2 M$, and $1 M_{d}$ polytypes, although partial $10-\AA$ periodicity occurs in the latter. Berthierine shows random stacking (Figure 5a); however, a two-layer polytype was found (Figure 5b). Sudoite shows random stacking (Figure 5c), and chlorite is usually semi-random (Figure 5d). Sometimes, semi-random stacking (Figure 6, inset) is observed for sudoite. Figure 6 shows the lattice image of semi-randomly stacked sudoite showing short-range order. Also visible is a twin plane, which may help produce semirandom stacking when repeated frequently.

A sequence of irregular stacking to produce apparent layers of $24-\AA(10+14)$ with some additional 14 $\AA$ layers is shown in Figure 7 . The $24-\AA$ layers may belong to a corrensite (chlorite + trioctahedral smectite) or mica + chlorite interlayering. Microdiffraction indicates spacing at $24 \AA$, and the lattice-fringe image shows open layers suggesting smectite layers (see Figure 7). Moreover, isolated layers with $24-\AA$ or $10-\AA$ intercalations within a chlorite and/or a berthierine crystal are common.

\section{Chemical composition of the mineral phases}

Dioctahedral micas. Table 1 shows represented analyses and a mean and standard deviation for a larger set of analyses. The results indicate a lack of chemical homogeneity. $K$ is more abundant in the epizone, whereas the other zones are low in $\mathrm{K}$. The Upper Cambrian sample (C91-25) has low Na (Table 1) in contrast to the other samples, where this cation is absent.

Figure 8 shows phengitic (a, b, and c) and illitic (d) components, represented only by the mean values of each sample (Table 1). Figure 8a shows for sample ZL-11 (epizone) a higher total $\mathrm{Fe}+\mathrm{Mg} v s$. Al content than expected by the degree of phengite components alone, which implies the possible presence of $\mathrm{Fe}^{3+}$ substituting for $\mathrm{Al}$ (that is, a ferrimuscovite compo- 

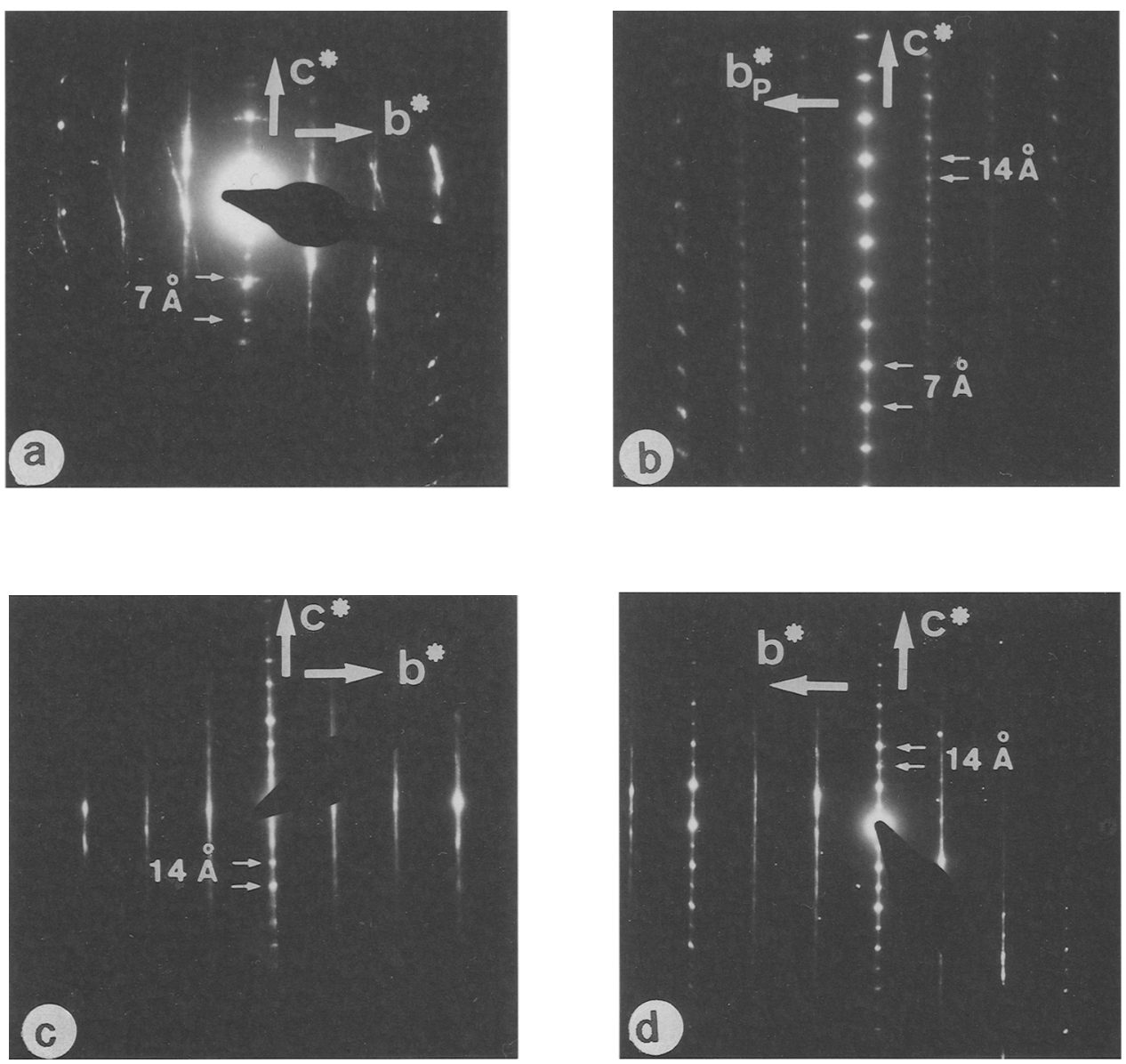

Figure 5. SAED patterns of a) berthierine disordered stacking; b) two-layer polytype of berthierine; c) disordered sudoite; d) semi-random stacking of the trioctahedral chlorite. $b_{p}^{*}$ : pseudo- $b^{*}$ axis. Sample C91-25.

nent). Figure $8 \mathrm{~b}$ and $8 \mathrm{c}$ confirms a ferrimuscovite substitution, which is evident in the epizone sample but only slightly in the others, which are near to ideal phengite.

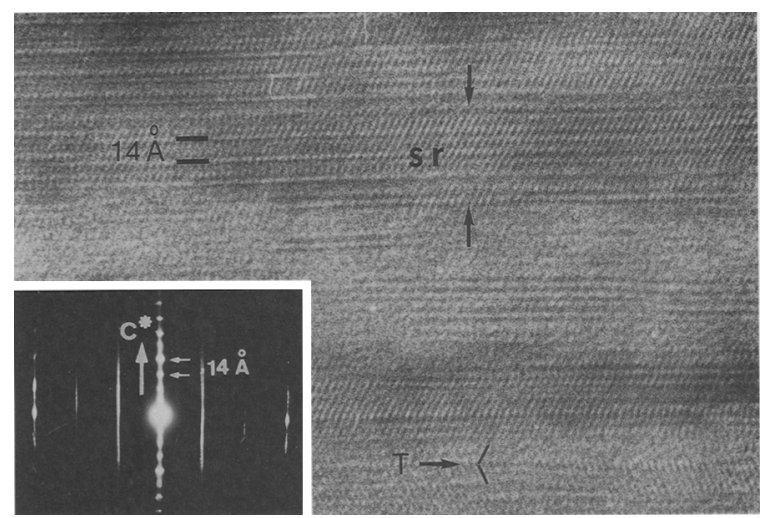

Figure 6. Lattice-fringe image and SAED patterns (inset) of sudoite with disordered stacking showing short-range ordering (sr) and a twin plane (T). Sample C91-25.

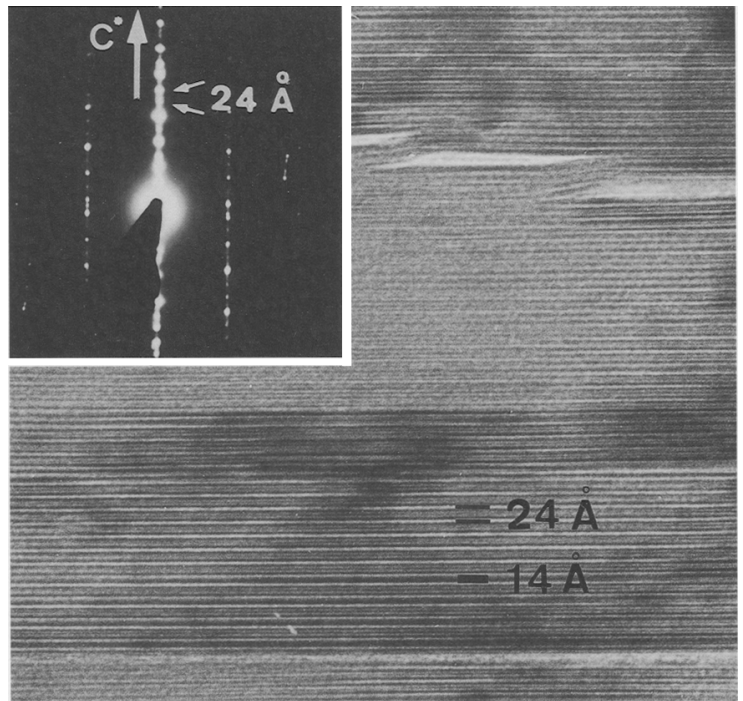

Figure 7. Corrensite lattice-fringe image and SAED patterns (inset) of the diagenetic sample (C91-25). 
Table 1. Representative AEM data for dioctahedral mica normalized to $\mathrm{O}_{10}(\mathrm{OH})_{2}$.

\begin{tabular}{|c|c|c|c|c|c|c|c|c|c|c|}
\hline Sample & $\mathrm{Si}$ & ${ }^{\mathrm{IV}} \mathrm{Al}$ & $v^{v_{1}} \mathrm{Al}$ & $\mathrm{Mg}$ & $\mathrm{Fe}$ & Ti & SOct & $\mathrm{K}$ & $\mathrm{Na}$ & $\sum \operatorname{Int}$ \\
\hline \multicolumn{11}{|l|}{ ZL-11 } \\
\hline 1 & 3.16 & 0.84 & 1.58 & 0.22 & 0.26 & 0.02 & 2.08 & 1.09 & b.d. & 1.09 \\
\hline 4 & 3.21 & 0.79 & 1.60 & 0.24 & 0.25 & 0.01 & 2.10 & 1.00 & b.d. & 1.00 \\
\hline 5 & 3.13 & 0.87 & 1.52 & 0.26 & 0.33 & 0.03 & 2.14 & 1.06 & b.d. & 1.06 \\
\hline 8 & 3.14 & 0.86 & 1.61 & 0.25 & 0.25 & b.d. & 2.10 & 1.04 & b.d. & 1.04 \\
\hline 11 & 3.20 & 0.80 & 1.60 & 0.25 & 0.27 & 0.03 & 2.15 & 0.90 & b.d. & 0.90 \\
\hline 12 & 3.12 & 0.88 & 1.77 & 0.18 & 0.15 & b.d. & 2.10 & 0.91 & b.d. & 0.91 \\
\hline 17 & 3.18 & 0.82 & 1.58 & 0.26 & 0.29 & 0.02 & 2.15 & 0.93 & b.d. & 0.93 \\
\hline 19 & 3.25 & 0.75 & 1.54 & 0.26 & 0.31 & 0.02 & 2.13 & 0.95 & b.d. & 0.95 \\
\hline 20 & 3.37 & 0.63 & 1.64 & 0.20 & 0.24 & 0.01 & 2.09 & 0.81 & b.d. & 0.81 \\
\hline 22 & 3.28 & 0.72 & 1.71 & 0.20 & 0.25 & 0.03 & 2.19 & 0.64 & b.d. & 0.64 \\
\hline Mean 16 An. & 3.21 & 0.79 & 1.61 & 0.24 & 0.26 & 0.02 & 2.12 & 0.94 & n.d. & 0.94 \\
\hline Std & 0.08 & 0.08 & 0.07 & 0.04 & 0.05 & 0.01 & 0.03 & 0.12 & n.d. & 0.12 \\
\hline \multicolumn{11}{|l|}{ LP-6 } \\
\hline 1 & 3.24 & 0.76 & 1.71 & 0.24 & 0.16 & 0.02 & 2.13 & 0.79 & b.d. & 0.79 \\
\hline 2 & 3.14 & 0.86 & 1.75 & 0.27 & 0.11 & 0.01 & 2.14 & 0.82 & b.d. & 0.82 \\
\hline 3 & 3.27 & 0.73 & 1.87 & 0.09 & 0.11 & b.d. & 2.06 & 0.67 & 0.07 & 0.74 \\
\hline 4 & 3.37 & 0.63 & 1.72 & 0.19 & 0.17 & b.d. & 2.08 & 0.76 & b.d. & 0.76 \\
\hline 7 & 3.40 & 0.60 & 1.84 & 0.17 & 0.07 & b.d. & 2.08 & 0.59 & b.d. & 0.59 \\
\hline 8 & 3.42 & 0.58 & 1.50 & 0.25 & 0.32 & b.d. & 2.07 & 0.93 & b.d. & 0.93 \\
\hline 12 & 3.22 & 0.78 & 1.76 & 0.18 & 0.15 & 0.01 & 2.10 & 0.81 & b.d. & 0.81 \\
\hline 13 & 3.18 & 0.82 & 1.71 & 0.19 & 0.13 & 0.01 & 2.04 & 1.03 & b.d. & 1.03 \\
\hline 17 & 3.13 & 0.87 & 1.77 & 0.14 & 0.18 & 0.01 & 2.10 & 0.91 & b.d. & 0.91 \\
\hline 19 & 3.11 & 0.89 & 1.78 & 0.21 & 0.10 & 0.01 & 2.09 & 0.93 & b.d. & 0.93 \\
\hline 25 & 3.12 & 0.88 & 1.95 & 0.08 & 0.03 & 0.01 & 2.07 & 0.79 & b.d. & 0.79 \\
\hline Mean 21 An. & 3.24 & 0.76 & 1.76 & 0.18 & 0.14 & 0.01 & 2.09 & 0.82 & n.d. & 0.83 \\
\hline Std & 0.12 & 0.12 & 0.11 & 0.06 & 0.07 & 0.01 & 0.03 & 0.13 & n.d. & 0.12 \\
\hline \multicolumn{11}{|l|}{ C-90-7 } \\
\hline 2 & 3.26 & 0.74 & 1.72 & 0.22 & 0.16 & 0.01 & 2.11 & 0.80 & b.d. & 0.80 \\
\hline 6 & 3.22 & 0.78 & 1.75 & 0.15 & 0.15 & b.d. & 2.05 & 0.94 & b.d. & 0.94 \\
\hline 8 & 3.34 & 0.66 & 1.90 & 0.12 & 0.07 & b.d. & 2.09 & 0.58 & b.d. & 0.58 \\
\hline 9 & 3.19 & 0.81 & 1.81 & 0.12 & 0.14 & 0.01 & 2.07 & 0.86 & b.d. & 0.86 \\
\hline 10 & 3.29 & 0.71 & 1.76 & 0.14 & 0.20 & 0.01 & 2.11 & 0.72 & b.d. & 0.72 \\
\hline 15 & 3.32 & 0.68 & 1.83 & 0.13 & 0.12 & 0.02 & 2.10 & 0.64 & b.d. & 0.64 \\
\hline 16 & 3.09 & 0.91 & 1.75 & 0.19 & 0.11 & 0.02 & 2.07 & 0.97 & 0.06 & 1.03 \\
\hline 18 & 3.40 & 0.60 & 1.71 & 0.13 & 0.10 & b.d. & 1.94 & 1.02 & b.d. & 1.02 \\
\hline 20 & 3.08 & 0.92 & 1.78 & 0.21 & 0.07 & 0.03 & 2.09 & 0.97 & b.d. & 0.97 \\
\hline 21 & 3.12 & 0.88 & 1.86 & 0.15 & 0.07 & 0.03 & 2.11 & 0.79 & b.d. & 0.79 \\
\hline Mean 19 An. & 3.23 & 0.77 & 1.79 & 0.16 & 0.12 & 0.01 & 2.07 & 0.83 & n.d. & 0.84 \\
\hline Std & 0.11 & 0.11 & 0.06 & 0.04 & 0.04 & 0.01 & 0.05 & 0.15 & n.d. & 0.16 \\
\hline \multicolumn{11}{|l|}{ C-91-25 } \\
\hline 1 & 3.16 & 0.84 & 1.79 & 0.16 & 0.12 & 0.01 & 2.07 & 0.90 & b.d. & 0.90 \\
\hline 3 & 3.21 & 0.79 & 1.83 & 0.13 & 0.08 & b.d. & 2.04 & 0.80 & 0.08 & 0.88 \\
\hline 6 & 3.16 & 0.84 & 1.76 & 0.18 & 0.14 & b.d. & 2.07 & 0.89 & 0.05 & 0.94 \\
\hline 7 & 3.33 & 0.67 & 1.55 & 0.30 & 0.26 & 0.01 & 2.12 & 0.81 & 0.07 & 0.88 \\
\hline 8 & 3.24 & 0.76 & 1.74 & 0.21 & 0.10 & b.d. & 2.04 & 0.82 & 0.12 & 0.94 \\
\hline 10 & 3.22 & 0.78 & 1.80 & 0.12 & 0.11 & 0.01 & 2.04 & 0.90 & b.d. & 0.90 \\
\hline 11 & 3.21 & 0.79 & 1.79 & 0.16 & 0.12 & 0.02 & 2.08 & 0.84 & b.d. & 0.84 \\
\hline 12 & 3.22 & 0.78 & 1.90 & 0.09 & 0.06 & b.d. & 2.05 & 0.64 & 0.13 & 0.77 \\
\hline 13 & 3.27 & 0.73 & 1.78 & 0.16 & 0.15 & b.d. & 2.09 & 0.66 & 0.11 & 0.77 \\
\hline 14 & 3.22 & 0.78 & 1.85 & 0.10 & 0.03 & b.d. & 1.98 & 0.93 & 0.04 & 0.97 \\
\hline 27 & 3.19 & 0.81 & 1.86 & 0.07 & 0.14 & 0.01 & 2.08 & 0.71 & 0.07 & 0.78 \\
\hline Mean & 3.22 & 0.78 & 1.79 & 0.15 & 0.12 & 0.01 & 2.06 & 0.81 & 0.06 & 0.87 \\
\hline Std & 0.05 & 0.05 & 0.09 & 0.06 & 0.06 & 0.01 & 0.04 & 0.10 & 0.03 & 0.07 \\
\hline
\end{tabular}

Note: b.d. Below detection. n.d. Not determined. Std standard deviation. 

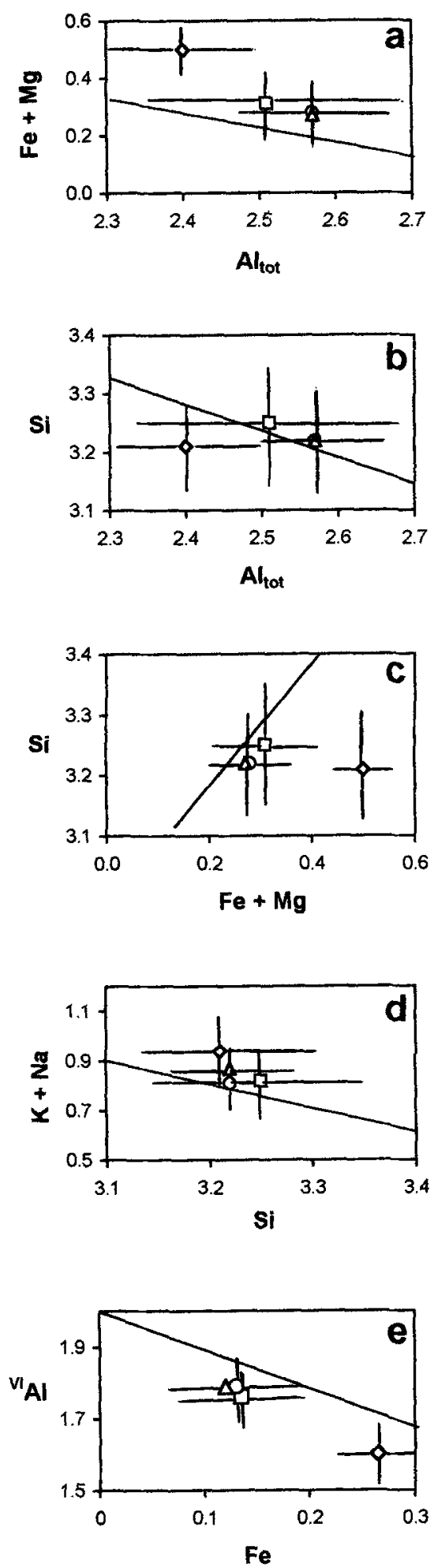

Figure 8. Mean-value diagrams of the dioctahedral K-rich mica. Phengitic content is represented in diagrams $a, b$, and c; d) shows illite substitution; e) ${ }^{\mathrm{VI}} \mathrm{Al}-\mathrm{Fe}^{3+}$ substitution. Lines show the ideal substitutions. $\diamond$ : sample ZL-11 (epizone); $\square$ : sample LP-6 (anchizone); O: sample C90-7 (diagenesis); $\triangle$ : sample C91-25 (diagenesis).
Figure 8d shows an illitic substitution in the diagenetic and anchizone samples. Representative values are plotted, and the values of Si content plot above those expected for pure illite. Excess Si is caused by both illite and phengite components.

Assuming that all $\mathrm{Fe}$ is ferric iron, an inverse relation between $\mathrm{Fe}^{3+}$ and $\mathrm{Al}$ (Figure 8e) is noted. Guidotti et al. (1994) showed that even in medium redox parageneses, $>60 \%$ of the $\mathrm{Fe}$ in muscovite is $\mathrm{Fe}^{3+}$. The following formulae are based on all iron as $\mathrm{Fe}^{3+}$ and this produces more reasonable results of occupancy: ZL-1 1: $\left(\mathrm{Si}_{3.17} \mathrm{Al}_{0.83}\right) \mathrm{O}_{10}(\mathrm{OH})_{2}\left(\mathrm{Al}_{1.54} \mathrm{Mg}_{0.24} \mathrm{Fe}_{0.26} \mathrm{Ti}_{0.02}\right)_{\Sigma=2.06}$ $\mathrm{K}_{0.93}$; LP-6: $\left(\mathrm{Si}_{3.23} \mathrm{Al}_{0.77}\right) \mathrm{O}_{10}(\mathrm{OH})_{2}\left(\mathrm{Al}_{1.72} \mathrm{Mg}_{0.18} \mathrm{Fe}_{0.13^{-}}\right.$ $\left.\mathrm{Ti}_{0.01}\right)_{i=2.04} \mathrm{~K}_{0.82} ;$ C90-7: $\left(\mathrm{Si}_{3.20} \mathrm{Al}_{0.80}\right) \mathrm{O}_{10}(\mathrm{OH})_{2}\left(\mathrm{Al}_{1.75} \mathrm{Mg}_{0.15^{-}}\right.$ $\left.\mathrm{Fe}_{0.13} \mathrm{Ti}_{0.01}\right)_{\Sigma=2.01}\left(\mathrm{~K}_{0.80} \mathrm{Na}_{0.01}\right)$; C91-25: $\left(\mathrm{Si}_{3.20} \mathrm{Al}_{0.80}\right) \mathrm{O}_{10^{-}}$ $(\mathrm{OH})_{2}\left(\mathrm{Al}_{1.76} \mathrm{Mg}_{0.15} \mathrm{Fe}_{0.12} \mathrm{Ti}_{0.01}\right)_{\Sigma=2.04}\left(\mathrm{~K}_{0.81} \mathrm{Na}_{0.06}\right)$. Thus, the three samples of equal or lower grade than anchizone have nearly identical composition, with the exception of a very small paragonite component. Illitic ( $\sim 0.8$ atoms per formula unit, a.f.u., of $\mathrm{K})$ and phengitic components are involved with $\sim 0.15$ a.f.u. $\mathrm{Mg}$ +0.13 a.f.u. Fe. The ferrimuscovite component is important in the epizone sample, which also has abundant phengite $(\mathrm{Mg}=0.24$ a.f.u.) and a near absence of illite $(\mathrm{K}=0.94$ a.f.u. $)$.

Berthierine, chamosite, sudoite, and corrensite. Table 2 shows the AEM analyses on chloritic materials from sample C91-25. Sudoite (Table 2) was deduced because the sum of the octahedral cations is nearly equal to 5 and the Si content is higher than in trioctahedral chlorite (hereafter, chamosite where Fe rich).

Differences in chemical composition are presented in Figure 9, where well-differentiated compositional fields are seen. Chamosite and berthierine comprise a field, with a high proportion of Fe. These two phases have identical chemical compositions when they coexist in the same sample (Abad and Nieto, 1995), only distinguishable by SAED and HRTEM. Sudoite which is characterized by high Si and ${ }^{V I} \mathrm{Al}$ contents and less Fe than berthierine-chamosite comprises another field.

A small amount of $\mathbf{K}$ indicates mica contamination. If the mica component is subtracted (Nieto, 1997) from the average value of each mineral phase, we obtain the following formulae with somewhat improved sums of octahedral cations and maintaining the same cationic proportions: sudoite: $\left(\mathrm{Si}_{3.55} \mathrm{Al}_{0.45}\right) \mathrm{O}_{10}(\mathrm{OH})_{8}$ $\left(\mathrm{Al}_{1.87} \mathrm{Mg}_{1.34} \mathrm{Fe}_{2.01} \mathrm{Ti}_{0.03} \mathrm{Mn}_{0.01}\right)_{\mathbf{2}=5.26}$; berthierine: $\left(\mathrm{Si}_{2.67^{-}}\right.$ $\left.\mathrm{Al}_{1.33}\right) \mathrm{O}_{10}(\mathrm{OH})_{8}\left(\mathrm{Al}_{1.48} \mathrm{Mg}_{1.11} \mathrm{Fe}_{3.32} \mathrm{Mn}_{0.02}\right)_{\Sigma=5.93}$; chamosite: $\left(\mathrm{Si}_{2.54} \mathrm{Al}_{1.46}\right) \mathrm{O}_{10}(\mathrm{OH})_{8}\left(\mathrm{Al}_{1.32} \mathrm{Mg}_{1.27} \mathrm{Fe}_{3.44} \mathrm{Ti}_{0.0 \mathrm{~J}}-\right.$ $\left.\mathrm{Mn}_{0.02}\right)_{\mathbf{X}}=6.06$.

One analysis, intermediate in composition between mica and chlorite, corresponds to the crystal with an apparent $24-\AA$ spacing (Figure 7). Owing to its scarcity, it was not possible to verify by XRD whether this crystal is corrensite or an interlayered mica-chlorite. 
Table 2. AEM data for chloritic minerals normalised to $\mathrm{O}_{10}(\mathrm{OH})_{8}$. Sample C91-25.

\begin{tabular}{|c|c|c|c|c|c|c|c|c|c|c|c|c|}
\hline An. & $\mathrm{Si}$ & $\mathrm{v}_{\mathrm{Al}}$ & "Al & $\mathrm{Mg}$ & $\mathrm{Fe}$ & $\mathrm{Ti}$ & $\mathrm{Mn}$ & EOct & $\mathrm{K}$ & $\mathrm{Na}$ & $\mathrm{Ca}$ & EInt \\
\hline \multicolumn{13}{|l|}{ Sudoite } \\
\hline 5 & 3.55 & 0.45 & 2.53 & 0.81 & 1.43 & 0.03 & 0.01 & 4.82 & 0.29 & b.d. & b.d. & 0.29 \\
\hline 15 & 3.46 & 0.54 & 2.31 & 0.65 & 2.03 & 0.02 & b.d. & 5.02 & 0.20 & b.d. & b.d. & 0.20 \\
\hline 18 & 3.66 & 0.34 & 2.18 & 1.56 & 1.23 & 0.03 & 0.01 & 5.01 & 0.13 & b.d. & b.d. & 0.13 \\
\hline 23 & 3.80 & 0.20 & 2.47 & 0.70 & 1.60 & 0.01 & 0.02 & 4.80 & 0.12 & b.d. & b.d. & 0.12 \\
\hline 29 & 3.72 & 0.28 & 2.15 & 1.08 & 1.63 & 0.09 & b.d. & 4.94 & 0.25 & b.d. & b.d. & 0.25 \\
\hline $8^{1}$ & 3.61 & 0.39 & 1.80 & 1.36 & 2.04 & 0.01 & b.d. & 5.21 & 0.06 & 0.10 & 0.01 & 0.17 \\
\hline $27^{1}$ & 3.78 & 0.22 & 2.33 & 1.20 & 1.38 & b.d. & b.d. & 4.91 & 0.07 & b.d. & b.d. & 0.07 \\
\hline $28^{1}$ & 3.55 & 0.45 & 1.92 & 1.42 & 1.88 & b.d. & 0.03 & 5.25 & 0.03 & b.d. & b.d. & 0.03 \\
\hline $34^{1}$ & 3.52 & 0.48 & 2.01 & 1.28 & 1.84 & b.d. & 0.01 & 5.14 & 0.20 & b.d. & b.d. & 0.20 \\
\hline $35^{1}$ & 3.84 & 0.16 & 1.66 & 1.95 & 1.59 & 0.06 & b.d. & 5.25 & b.d. & b.d. & b.d. & b.d. \\
\hline Mean 14 An. & 3.63 & 0.37 & 2.07 & 1.19 & 1.78 & 0.03 & 0.01 & 5.08 & 0.15 & n.d. & n.d. & 0.14 \\
\hline Std & 0.13 & 0.13 & 0.29 & 0.41 & 0.28 & 0.03 & 0.01 & 0.17 & 0.09 & n.d. & n.d. & 0.09 \\
\hline \multicolumn{13}{|l|}{ Berthierine } \\
\hline $3^{1}$ & 2.55 & 1.45 & 1.59 & 1.11 & 3.23 & b.d. & b.d. & 5.93 & b.d. & b.d. & b.d. & b.d. \\
\hline $8^{1}$ & 2.54 & 1.46 & 1.64 & 1.25 & 2.92 & b.d. & b.d. & 5.81 & b.d. & 0.20 & b.d. & 0.20 \\
\hline $26^{1}$ & 2.75 & 1.25 & 1.64 & 1.26 & 2.82 & 0.02 & 0.03 & 5.78 & 0.05 & b.d. & b.d. & 0.05 \\
\hline $30^{1}$ & 2.79 & 1.21 & 1.69 & 1.13 & 2.78 & 0.01 & 0.03 & 5.64 & 0.05 & 0.18 & b.d. & 0.23 \\
\hline $31^{1}$ & 2.66 & 1.34 & 1.54 & 1.33 & 3.00 & b.d. & 0.03 & 5.90 & b.d. & b.d. & b.d. & b.d. \\
\hline $33^{1}$ & 2.60 & 1.40 & 1.62 & 1.26 & 2.95 & b.d. & 0.04 & 5.87 & 0.05 & b.d. & b.d. & 0.05 \\
\hline Mean & 2.65 & 1.35 & 1.62 & 1.22 & 2.95 & 0.01 & 0.02 & 5.82 & 0.03 & 0.06 & n.d. & 0.09 \\
\hline Std & 0.10 & 0.10 & 0.05 & 0.09 & 0.16 & 0.01 & 0.02 & 0.10 & 0.03 & 0.10 & n.d. & 0.10 \\
\hline \multicolumn{13}{|l|}{ Chamosite } \\
\hline $12^{1}$ & 2.86 & 1.14 & 1.58 & 1.03 & 3.00 & 0.01 & 0.02 & 5.64 & 0.03 & 0.22 & 0.03 & 0.28 \\
\hline $15^{\prime}$ & 2.61 & 1.39 & 1.54 & 1.16 & 3.12 & b.d. & 0.03 & 5.85 & 0.13 & b.d. & 0.02 & 0.15 \\
\hline $18^{1}$ & 2.79 & 1.21 & 1.65 & 1.19 & 2.85 & 0.03 & 0.02 & 5.74 & 0.08 & b.d. & b.d. & 0.08 \\
\hline Mean & 2.75 & 1.25 & 1.59 & 1.13 & 2.99 & 0.01 & 0.02 & 5.74 & 0.08 & 0.07 & 0.02 & 0.17 \\
\hline Std & 0.13 & 0.13 & 0.06 & 0.09 & 0.14 & 0.02 & 0.01 & 0.10 & 0.05 & 0.13 & 0.02 & 0.10 \\
\hline \multicolumn{13}{|c|}{ Berthierine-chamosite undifferentiated } \\
\hline 16 & 2.97 & 1.03 & 1.61 & 0.87 & 3.12 & b.d. & 0.02 & 5.62 & 0.09 & b.d. & 0.09 & 0.18 \\
\hline 17 & 3.02 & 0.98 & 1.69 & 0.75 & 3.14 & b.d. & 0.03 & 5.61 & 0.08 & b.d. & b.d. & 0.08 \\
\hline 20 & 2.66 & 1.34 & 0.98 & 0.55 & 4.57 & 0.01 & 0.01 & 6.11 & 0.13 & b.d. & b.d. & 0.13 \\
\hline 21 & 2.87 & 1.13 & 1.83 & 0.75 & 3.00 & 0.01 & 0.02 & 5.61 & 0.08 & b.d. & b.d. & 0.08 \\
\hline 25 & 2.73 & 1.27 & 1.63 & 1.28 & 2.86 & b.d. & 0.03 & 5.80 & 0.03 & b.d. & b.d. & 0.03 \\
\hline 26 & 3.05 & 0.95 & 1.93 & 0.97 & 2.57 & b.d. & 0.01 & 5.48 & 0.06 & b.d. & b.d. & 0.06 \\
\hline Mean & 2.88 & 1.12 & 1.61 & 0.86 & 3.21 & n.d. & 0.02 & 5.71 & 0.08 & n.d. & n.d. & 0.09 \\
\hline Std & 0.16 & 0.16 & 0.33 & 0.25 & 0.70 & n.d. & 0.01 & 0.22 & 0.03 & n.d. & n.d. & 0.05 \\
\hline \multicolumn{13}{|l|}{ Corrensite } \\
\hline $13^{1}$ & 3.06 & 0.94 & 1.49 & 2.05 & 2.09 & b.d. & 0.01 & 5.65 & 0.12 & b.d. & 0.03 & 0.15 \\
\hline
\end{tabular}

${ }^{1}$ Analysis from ion-thinned sample. Chamosite and berthierine differentiated by SAED and HRTEM.

Nonetheless, if the formula is normalized to 25 oxygen atoms, as suggested by Shau et al. (1990), the formula based on corrensite is: $\left(\mathrm{Si}_{5.41} \mathrm{Al}_{2.54}\right) \mathrm{O}_{20}(\mathrm{OH})_{10}\left(\mathrm{Al}_{1.77^{-}}\right.$ $\left.\mathrm{Mg}_{3.71} \mathrm{Fe}_{3.64}\right)_{\Sigma=9.14}\left(\mathrm{~K}_{0.21} \mathrm{Ca}_{0.05}\right)$. The proportions show that this crystal is equal to corrensite in the study of Shau et al. (1990) (see their Table 3, analyses $7 \mathrm{~b}$ and $8 b$ ), although with some chemical differences: (1) a greater proportion of $\mathrm{Al}$ and (2) $\mathrm{K}$ instead of $\mathrm{Ca}$ as the dominant interlayer cation. $\mathrm{Fe}$ and $\mathrm{Mg}$ are in similar proportions. The sum of octahedral cations is $\sim 9$ a.f.u. ( 6 from trioctahedral chlorite +3 from the smectite-like phase) and the interlayer cations sum to 0.25 a.f.u. If this phase is a mixed-layer mica-chlorite, the sum of the octahedral cations would be 8 and the interlayer cations would add to 1 a.f.u.

\section{DISCUSSION}

The observed rock textures are not typical of finegrained pelitic rock as described by others (e.g., Ahn and Peacor, 1986). Owing to the greater percentage of coarse detritic material, directed pressure does not produce phyllosilicates as near parallel packets, but instead phyllosilicates rim quartz and albite grains (Figure 1). Consequently, phyllosilicate packets are frequently crossed, forming wide angles (Figure 2) that are uncommon in samples from pelitic sequences.

The only apparent change in the texture occurring with metamorphic grade involves the size and number of crystalline defects. Thus, phyllosilicate packets are wider and more defect-free with increasing metamorphic grade $(\sim 15$ layers in the shallow diagenetic zone 

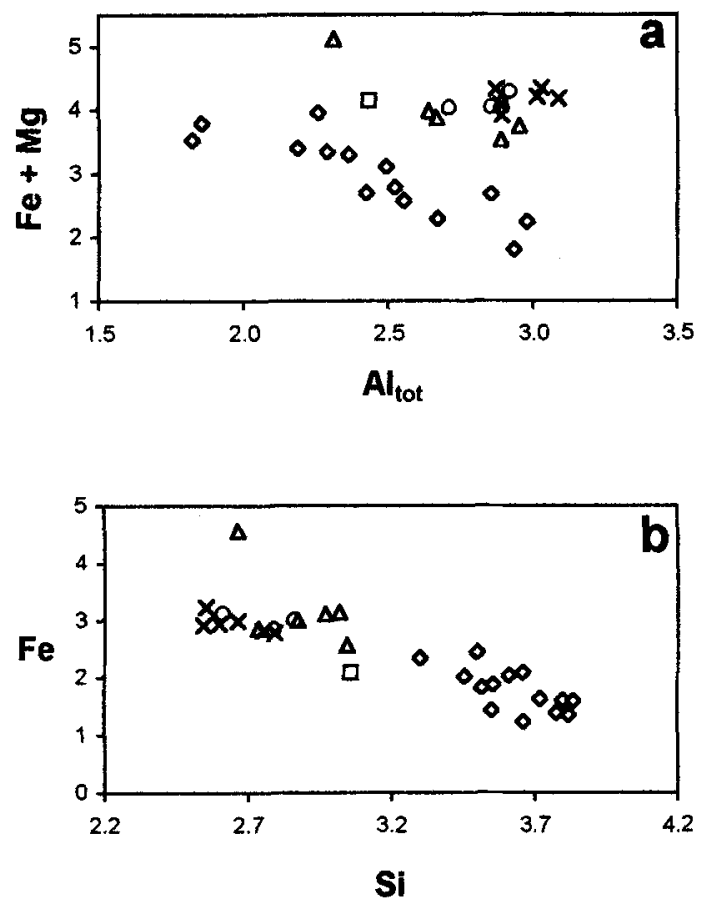

Figure 9. Compositional differences between chloritic materials from sample C91-25. a) total $\mathrm{Al}$ vs. $\mathrm{Fe}+\mathrm{Mg}$; b) $\mathrm{Si}$ vs. Fe. $\diamond$ : sudoite; $\mathrm{x}$ : berthierine; $O$ : chamosite; $\triangle$ : berthierine-chamosite undifferentiated; $\square$ : corrensite.

to $>80$ layers in the epizone), which is consistent with the results of Merriman et al. (1990) and Warr and Nieto (1998) and the physical meaning of IC. Although, this parameter cannot be used as the only guide to establish the grade of metamorphism because of kinetic factors, it does provide a good approximation to describe metamorphic grade, as determined from many geological terrains (Kisch, 1987).

The lowest-grade diagenetic sample, C91-25, is similar to the highest-grade sample from the BasqueCantabrian Basin, both chemically (see Nieto et al., 1996, Table 1, sample CG-5) and texturally. Sample CG-5 of Nieto et al. (1996) represents a link between burial diagenesis (Basque-Cantabrian Basin) and the initiation of tectonic metamorphism (this study).

The $1 M$ and $2 M$ polytypes of the white-micas are present in all samples. The $1 M_{d}$ polytype occurs in the anchizone and diagenetic zone, but apparent long-period polytypes occur only in the epizone sample. The coexistence of these polytypes indicates a lack of equilibrium throughout the series, and local conditions must determine which polytypes are present. Hence, the occurrence of different polytypes is independent of the general metamorphic conditions.

Only the epizone shows a change in composition of dioctahedral micas, passing from $\sim 0.82$ a.f.u. interlayer cations (illite) in the diagenesis and anchizone to 0.94 a.f.u. interlayer cations (muscovite/phengite) in the epizone. A compositional gap seems to occur between illite and phengite, with illite in the diagenetic zone and anchizone to phengite in the epizone, with no intermediate steps between one mineral phase and the other, similar to what was found by Jiang $e t$ al. (1992). The greater amount of ferrimuscovite in the epizone sample (ZL-11) is likely related to the wholerock composition; López-Munguira et al. (1996) found a ratio of $\mathrm{FeO} / \mathrm{Fe}_{2} \mathrm{O}_{3}=0.14$ for epizone rocks, as compared to 0.33 for the anchizone and 0.61 for the diagenesis. Guidotti et al. (1994) showed that the opaque assemblage (e.g., hematite in sample ZL-11) may be used to estimate the $\mathrm{Fe}^{3+} / \mathrm{Fe}^{2+}$ ratio in muscovite and that oxidation state is the main factor controlling the extent to which ${ }^{\mathrm{V}} \mathrm{Al}$ is replaced by $\mathrm{Fe}^{3+}$.

The coexistence of sudoite, berthierine, chamosite, and corrensite confirms lack of equilibrium, because the stability field of sudoite is at a lower temperature than that of trioctahedral chlorite (Fransolet and Schreyer, 1984; Franceschelli et al., 1989; Vidal et al., 1992) and berthierine is a metastable polymorph with the same composition of chlorite (Abad and Nieto, 1995). The chloritic materials show complete order to disorder in polytype stacking (Figure 5). The lattice image of sudoite (Figure 6) reveals short-range order, with interruptions by twin planes. However, longrange order is absent (inset, Figure 6).

Corrensite differs in composition from those described by others (e.g., Shau et al., 1990), with a high proportion of $\mathrm{Al}, \mathrm{K}$ as the interlayer cation, and $\mathrm{Fe}$ and $\mathrm{Mg}$ present in similar proportions. The evolution from smectite to chlorite in basic systems (Shau et al., 1990; Inoue and Utada, 1991) occurs through interstratification (including corrensite). Notwithstanding, in pelitic rocks, chlorite can crystallize directly (e.g., Peacor, 1992) owing to the $\mathrm{Fe} / \mathrm{Mg}$ bulk composition of the rock. When the proportion is $\mathrm{Fe}>\mathrm{Mg}$ (pelites), the evolution is direct, but when the proportion is $\mathrm{Fe}$ $<\mathrm{Mg}$ (basic rocks), corrensite is formed (Shau et al., 1990 ). In the pelitic sample here, the $\mathrm{Fe} / \mathrm{Mg}$ ratio of the rock is 3:1 (Lopez-Munguira et al., 1996), although the $\mathrm{Fe} / \mathrm{Mg}$ proportion of corrensite in sample C91-25 is approximately $1: 1$ (see Table 2); that is, it would represent a limiting ratio for corrensite formation. Therefore, with disequilibrium occurring for these environments, corrensite may or may not form, depending on the local chemistry for each sample area. Nevertheless, corrensite formed within pelitic rocks, would present a composition rich in $\mathrm{Al}, \mathrm{Fe}$, and $\mathrm{K}$, and Ca-poor which is consistent with the bulk chemistry of pelites.

\section{ACKNOWLEDGMENTS}

We thank T. Palacios for the geologic information on the samples and C. Laurin for the English revision. The help of M.M. Abad-Ortega (Centro de Instrumentación Científica, University of Granada) with the HRTEM and AEM and I. 
Nieto with the preparation of samples was essential for the present work. We are grateful to an anonymous referee and S. Guggenheim for valuable comments on the manuscript. Financial support was supplied by Research Project $n^{\circ}$ PB961383 of the Spanish Ministry of Education and Research Group RNM-0179 of the Junta de Andalucia.

\section{REFERENCES}

Abad, M.M. and Nieto, F. (1995) Genetic and chemical re lationships between berthierine, chlorite and cordierite in nodules associated to granitic pegmatites of Sierra Albarrana (Iberian Massif, Spain). Contributions to Mineralogy and Petrology, 120, 327-336.

Ahn, J.H. and Peacor, D.R. (1986) Transmission and analytical electron microscopy of the smectite to illite transition. Clays and Clay Minerals, 34, 165-179.

Ahn, J.H., Peacor, D.R., and Essene, E.J. (1985) Coexisting paragonite-phengite in blueschist eclogite: A TEM study. American Mineralogist, 70, 1193-1204.

Baronnet, A. (1992) Polytypism and stacking disorder. In Minerals and Reactions at the Atomic Scale: Transmission Electron Microscopy, Reviews in Mineralogy, Volume 27, P. Buseck and P.H. Ribbe, eds., Mineralogical Society of America, Washington, D.C., 231-282.

Baronnet, A. and Kang, Z.C. (1989) About the origin of mica polytypes. Phase Transitions, 16/17, 447-493.

Champness, P.E., Cliff, G., and Lorimer, G.W. (1981) Quantitative analytical electron microscopy. Bulletin of Mineralogy, 104, 236-240.

Cliff, G. and Lorimer, G.W. (1975) The quantitative analysis of thin specimens. Journal of Microscopy, 103, 203-207.

Dalla-Torre, M., Livi, K., Veblen, D.R., and Frey, M. (1996) White $\mathrm{K}$-mica evolution from phengite to muscovite in shales and shale matrix melange, Diablo Range, California Contributions to Mineralogy and Petrology, 123, 390-405.

Franceschelli, M., Mellini, M., Memmi, I., and Ricci, C.A. (1989) Sudoite, a rock-forming mineral in Verrucano of the Northern Apennines (Italy) and the sudoite-chloritoid-pyrophyllite assemblage in prograde metamorphism. Contributions to Mineralogy and Petrology, 101, 274-279.

Fransolet, A.M. and Schreyer, W. (1884) Sudoite, di/trioctahedral chlorite: A stable low-temperature phase in the system $\mathrm{MgO}-\mathrm{Al}_{2} \mathrm{O}_{3}-\mathrm{SiO}_{2}-\mathrm{H}_{2} \mathrm{O}$. Contributions to Mineralogy and Petrology, 86, 409-417.

Guidotti, C.V., Yates, M.G., Dyar, M.D., and Taylor, M.E. (1994) Petrogenetic implications of the $\mathrm{Fe}^{3+}$ contents of muscovite in pelitic schists. American Mineralogist, 79, 793-795.

Iijima, S. and Buseck, P.R. (1978) Experimental study of mica structures by high-resolution electron microscopy. Acta Crystallographica, A34, 709-719.

Inoue, A. and Utada, M. (1991) Smectite-to-chlorite transformation in thermally metamorphosed volcanoclastic rocks in the Kamikita area, Northern Honshu, Japan. American Mineralogist, 76, 628-640.

Jiang, W.T., Nieto, F, and Peacor, D.R. (1992) Composition of diagenetic illite as defined by analytical electron microscope analyses: Implications for smectite-illite-muscovite transitions. In 29th International Geological Congress Abstract, Volume 1, Kyoto, Japan, 100.

Julivert, M., Fontboté, J.M. Ribeiro, A., and Conde, L. (1974) Mapa Tectónico de la Península Ibérica y Baleares, Instituto Geológico y Minero de España, Madrid, 113 pp.

Kisch, H. (1987) Correlation between indicators of very lowgrade metamorphism. In Low Temperature Metamorphism, M. Frey ed., Blackie Press, Glasgow, 227-300.
Lee, J.H., Ahn, J.H., and Peacor, D.R. (1985) Textures in layered silicates: Progressive changes through diagenesis and low-temperature metamorphism. Journal of Sedimentology and Petrology, 55, 532-540.

Lindgreen, H. and Hansen, P.L. (1991) Ordering of illitesmectite in Upper Jurassic claystones from the North Sea. Clay Minerals, 26, 105-125.

López-Munguira, A., Nieto, F, and Sebastian-Pardo, E. (1993) Caracterización de las pizarras cámbricas de la Unidad Alconera (Zona de Ossa-Morena). Su utilidad como indicadores de las condiciones metamórficas. Geogaceta, 13, 69-71.

López-Munguira, A., Morata, D., and Nieto, F. (1996) Geoquímica de los materiales pelíticos cámbricos al noroeste de Zafra (Badajoz). Geogaceta, 22, 149-152.

López-Munguira, A., Nieto, F., and Morata, D. (1998) Metamorphic evolution from diagenesis to epizone in Cambrian formations from NW Zafra (Ossa-Morena zone, SW Spain). Neues Jahrbuch fïr Mineralogie, 174, 131-157.

Merriman, R.J., Roberts, B., and Peacor, D.R. (1990) A transmission electron microscope study of white mica crystallite size distribution in a mudstone to slate transitional sequence, North Wales, UK. Contributions to Mineralogy and Petrology, 106, 27-40.

Nieto, F. (1997) Chemical composition of metapelitic chlorites: X-ray diffraction and optical property approach. $E u$ ropean Journal of Mineralogy, 9, 829-842.

Nieto, F, Ortega-Huertas, M., Peacor, D.R., and Aróstegui, J. (1996) Evolution of illite/smectite from early diagenesis through incipient metamorphism in sediments of the Basque-Cantabrian Basin. Clays and Clay Minerals, 44, 304-323.

Peacor, D. (1992) Diagenesis and low-grade metamorphism of shales and slates. In Minerals and Reactions at the Atomic Scale: Transmission Electron Microscopy, Reviews in Mineralogy, Volume 27, P. Buseck and P.H. Ribbe, eds., Mineralogical Society of America, Washington, D.C., 335 376.

Ross, M., Takeda, H., and Wones, D.R. (1966) Mica polytypes: Systematic description and identification. Science, 151, 191-193.

Shau, Y.H., Peacor, D.R., and Essene, E.J. (1990) Corrensite and mixed-layer chlorite/corrensite in metabasalt from northern Taiwan: TEM/AEM, EMPA, XRD, and optical studies. Contributions to Mineralogy and Petrology, 105, 123-142.

Van Der Pluijm, B.A., Lee, J.H., and Peacor, D.R. (1988) Analytical electron microscopy and the problem of potassium diffusion. Clays and Clay Minerals, 36, 498-504.

Vidal, O., Goffé, B, and Theye, T. (1992) Experimental study of the stability of sudoite and magnesiocarpholite and calculation of a new petrogenetic grid for the system $\mathrm{FeO}$ $\mathrm{MgO}-\mathrm{Al}_{2} \mathrm{O}_{3}-\mathrm{SiO}_{2}-\mathrm{H}_{2} \mathrm{O}$. Journal of Metamorphic Geology, 10, 603-614.

Warr, L.N. and Nieto, F. (1998) Crystallite size distributions in very low grade metamorphic pelites: A HRTEM and XRD study of clay mineral crystallinity index standards. Canadian Mineralogist, 36, 1453-1474.

Yau, Y.C., Peacor, D.R., and McDowell, S.D. (1987) Smectite-to-illite reactions in Salton Sea shales: A transmission and analytical electron microscopy study. Journal of Sedimentology and Petrology, 57, 335-342.

E-mail of corresponding author: munguira@guadiana.unex.es

(Received 13 October 1998; accepted 25 October 1999; Ms. 98-124) 